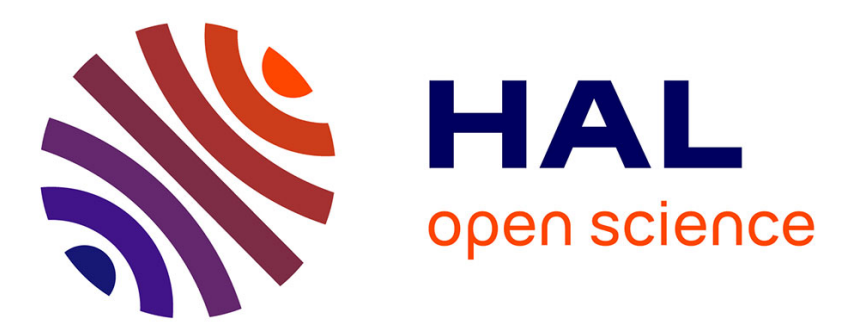

\title{
Millimeter-wave Heating in vitro: Local Microscale Temperature Measurements Correlated to Heat Shock Cellular Response
}

Rosa Orlacchio, Denys Nikolayev, Yann Le Page, Yves Le Drean, Maxim Zhadobov

\section{To cite this version:}

Rosa Orlacchio, Denys Nikolayev, Yann Le Page, Yves Le Drean, Maxim Zhadobov. Millimeterwave Heating in vitro: Local Microscale Temperature Measurements Correlated to Heat Shock Cellular Response. IEEE Transactions on Biomedical Engineering, 2022, 69 (2), pp.840-848. 10.1109/TBME.2021.3108038 . hal-03376846

\section{HAL Id: hal-03376846 \\ https://hal.science/hal-03376846}

Submitted on 15 Oct 2021

HAL is a multi-disciplinary open access archive for the deposit and dissemination of scientific research documents, whether they are published or not. The documents may come from teaching and research institutions in France or abroad, or from public or private research centers.
L'archive ouverte pluridisciplinaire HAL, est destinée au dépôt et à la diffusion de documents scientifiques de niveau recherche, publiés ou non, émanant des établissements d'enseignement et de recherche français ou étrangers, des laboratoires publics ou privés.

\section{(ㄷ)(1) $\$$}

Distributed under a Creative Commons Attribution - NonCommerciall 4.0 International 


\title{
Millimeter-Wave Heating in Vitro: Local Microscale Temperature Measurements Correlated to Heat Shock Cellular Response
}

\author{
Rosa Orlacchio, Denys Nikolayev, Member, IEEE, Yann Le Page, Yves Le Dréan, \\ Maxim Zhadobov, Senior Member, IEEE
}

\begin{abstract}
Objective: Cellular sensitivity to heat is highly variable depending on the cell line. The aim of this paper is to assess the cellular sensitivity of the A375 melanoma cell line to continuous (CW) millimeter-waves (MMW) induced heating at $58.4 \mathrm{GHz}$, between $37^{\circ} \mathrm{C}$ and $47^{\circ} \mathrm{C}$ to get a deeper insight into optimization of thermal treatment of superficial skin cancer. Methods: Phosphorylation of heat shock protein 27 (HSP27) was mapped within an area of about $30 \mathrm{~mm}^{2}$ to visualize the variation of heat-induced cellular stress as a function of the distance from the waveguide aperture (MMW radiation source). A multiphysics computational approach was then adopted to yield both electromagnetic and thermal field distributions as well as corresponding specific absorption rate (SAR) and temperature elevation. Induced temperature rise was experimentally measured using a micro-thermocouple ( $\mu \mathrm{TC})$. Results: Coupling of the incident electromagnetic (EM) field with $\mu$ TC leads was first characterized, and optimal $\mu \mathrm{TC}$ placing was identified. HSP27 phosphorylation was induced at temperatures $\geq$ $41^{\circ} \mathrm{C}$, and its level increases as a function of the thermal dose delivered, remaining mostly focused within $3 \mathrm{~mm}^{2}$. Conclusion: Phosphorylation of HSP27 represents a valuable marker of cellular stress of A375 melanoma cells under MMW exposure, providing both quantitative and spatial information about the distribution of the thermal stress. Significance: These results may contribute to the design of thermal treatments of superficial melanoma through MMWinduced heating in the hyperthermic temperature range.
\end{abstract}

Index Terms-Millimeter waves, multiphysics microdosimetry, heat shock response, hyperthermia, HSP27, thermocouple

\section{INTRODUCTION}

$\mathbf{T}$ HE increasing use of millimeter-wave (MMW) technologies (body-centric [1], 5G networks [2], automotive radars [3], security scanners [4], non-lethal weapons [5], etc.) has stimulated research on the interaction of MMW with the human body both in terms of dosimetry [6] and

This paragraph of the first footnote will contain the date on which you submitted your paper for review. (Corresponding author: Rosa Orlacchio).

Rosa Orlacchio is with Univ Limoges, CNRS, XLIM - UMR 7252, F87000, Limoges, France. (e-mail: rosaorlacchio@hotmail.it).

Denys Nikolayev and Maxim Zhadobov are with Univ Rennes, CNRS, IETR (Institut d'électronique et des technologies du numérique) - UMR 6164, F-35000, Rennes, France.

Yann Le Page and Yves Le Dréan an are with Univ Rennes, Inserm, EHESP, IRSET (Institut de Recherche en Santé Environnement et Travail) - UMR_ S 1085, F-35000, Rennes, France. elicited biological effects [7]-[9]. At the macroscopic level, MMW are rapidly absorbed by the superficial layers of the skin due to their low penetration depth $(1-10 \mathrm{~mm})$. At the microscopic level, exposure at these frequencies induces oscillations in polar molecules of free water, thereby raising their thermal energy. This results in heating of mainly high-water content tissues. MMW-induced heating can be exploited in the biomedical field for non-invasive and spatially localized thermal treatment of superficial skin cancers, such as spreading melanoma [10]. The latter is an aggressive tumor with high resistance to both chemotherapy and radiotherapy [11]. Its location is commonly within the $0.5-\mathrm{mm}$ layer in the skin, which corresponds to the MMW penetration depth around $60 \mathrm{GHz}$. By varying the frequency and exposure beam size, and by enforcing surface cooling, it is possible to accurately focus the heat within near-surface tumors minimizing damage to surrounding tissues [10]. This also makes possible to adjust the depth of maximum heating towards the desired skin layer depending on the tumor stage [10].

Cytotoxic effect of MMW-induced heating on melanoma cells was demonstrated in [12], [13]. Continuous-wave (CW)heating between 39 and $53^{\circ} \mathrm{C}$, induced by $42.25 \mathrm{GHz} \mathrm{MMW}$ reduces cellular viability of either human or murine melanoma cells from about $10 \%$ to $90 \%$ [13]. In addition, short thermal pulses induced by amplitude modulated pulsed-waves (PW) at $58.4 \mathrm{GHz}$, lead to stronger apoptosis of melanoma cells compared to $\mathrm{CW}$ heating with the same average temperature rise [12].

Cellular response to heat may largely vary depending on the cell line, temperature, and exposure duration [14], [15]. Therefore, the success of a thermal treatment strongly depends on: $i)$ the knowledge of the specific sensitivity to heat of the tissue of interest, $i i)$ the precise control of the temperature elevation during the treatment, and iii) focusing of thermal energy in the target area.

A severe heat shock $\left(>48{ }^{\circ} \mathrm{C}\right)$, delivered for a short duration, between few seconds and 4-6 minutes, may induce complete denaturation of proteins leading to direct cellular death [16]. Mild $\left(40-41^{\circ} \mathrm{C}\right.$ for $\left.6-72 \mathrm{~h}\right)$ or moderate $\left(42-47^{\circ} \mathrm{C}\right.$ for 15-60 $\mathrm{min}$ ) heat shock [16], may sensitize cells, thus enhancing the cytotoxic effect of radiotherapy and chemotherapy [17], or induce thermotolerance [18]. Indeed, cells possess a self-defense molecular mechanism mediated by a family 


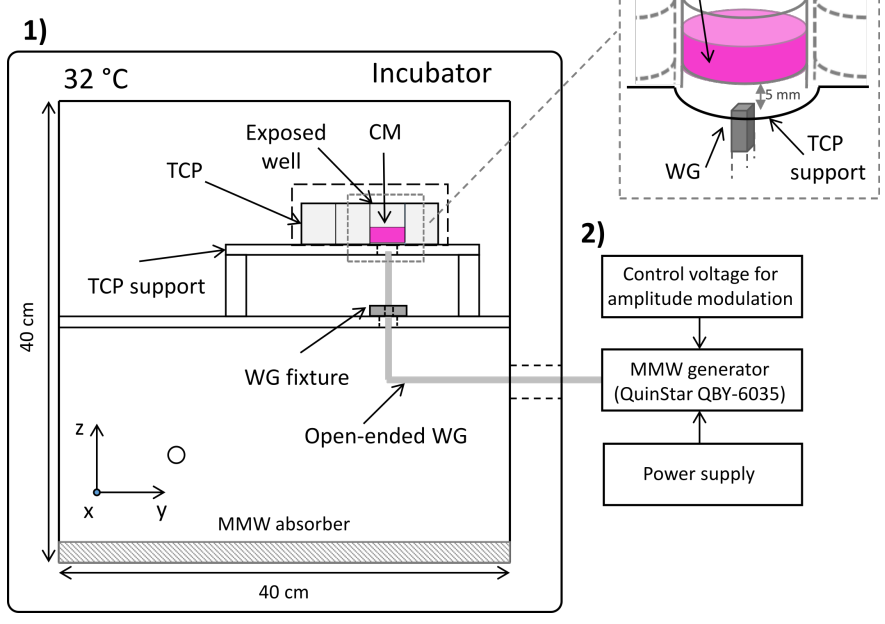

Fig. 1: Schematic of the exposure system developed for this study: 1) incubator containing the open-ended waveguide (WG), the tissue culture plate (TCP) and its plastic support, 2) signal generation unit. The inset (in the upper right corner) shows the exposed well filled with $2 \mathrm{ml}$ of culture medium.

of proteins called heat shock proteins (HSP) [19]. HSP are expressed under basal conditions and upregulated by proteotoxic stress (including mild heating [19]) to prevent unfolding, misfolding, or aggregation of the stressed proteins [20]. Note that development of thermotolerance depends on various parameters, including cell line, temperature and duration of the heat shock [18], [21].

In addition, a combination of nanoparticles-mediated thermal ablation and immunotherapies, known as synergistic immuno photothermal nanotherapy (SYMPHONY), appears to be a promising technique for local treatment of cancer [22], [23].

In this paper, we report a multiphysics microdosimetry study to assess sensitivity of A375 melanoma cell line to $\mathrm{CW}$ heating at $58.4 \mathrm{GHz}$ in the hyperthermic range between 37 and $47^{\circ} \mathrm{C}$. To this end, we used HSP27 as a marker of the heat-induced cellular stress. Its expression is an indicator of thermotolerance that must be minimized to guarantee the success of the thermal treatment. $\mathrm{CW}$-induced heating has been generated at the cellular level through a specific MMW-generator setup [12], [24]. A micro-thermocouple $(\mu \mathrm{TC})$ has been used to measure temperature elevation at the level of the exposed cell monolayer. Experimental results were complemented by multiphysics [electromagnetic (EM) and thermal $\left(\mathrm{T}^{\circ}\right)$ ] computations. Finally, heat-induced cellular stress was quantified, cell-by-cell, by analyzing the level of HSP27 phosphorylation 6 hours post-exposure via immunocytochemistry in order to obtain spatial variation of the HSP27 response within the exposed area.

\section{A. Exposure Set-up, Cell Culture, and Fluorescence Analysis}

Due to the shallow penetration of MMW, in vitro exposure of cell monolayers, lying on the bed of plastic tissue culture plates, is generally performed from the bottom [12], [25]. The exposure system used in this study is presented in Fig. 1 and described in detail in [24]. A WR15 waveguide (WG) aperture antenna, operating at $58.4 \mathrm{GHz}$, was used to drive the MMW radiation toward one well of the 12-well tissue culture plate set $5 \mathrm{~mm}$ from it (inset of Fig. 1).

The human malignant A375 melanoma cells (American Type Culture Collection, ATCC, Molsheim, FR) were grown in Dulbecco's modified Eagle medium (Gibco/Life Technologies, Carlsbad, CA) supplemented with $8 \%$ fetal calf serum (FCS), $1 \%$ antibiotics, and $1 \% \mathrm{~L}$-glutamine, under a controlled atmosphere $\left(37^{\circ} \mathrm{C}, 5 \% \mathrm{CO}_{2}, 95 \%\right.$ humidity $)$. Cell culture, exposure protocol, cell imaging, and fluorescence analysis of the exposed cells are described in [25]. The cells were cultured in three different wells of a 12-well culture plate and incubated for 48 hours. One well was exposed, while the other two were used as negative and positive controls (i.e., cells untreated or treated with a cytotoxic agent). For exposure, cells were transferred into the incubator containing the WG (Fig. 1) and left one hour at $32^{\circ} \mathrm{C}$ before exposure to compensate for a rapid temperature rise at the beginning of exposure (first minutes) and avoid cells overheating [12]. This allowed us to reach the desired temperature levels to trigger thermotolerance without inducing cellular death. Then, the cells were exposed for $90 \mathrm{~min}$ and subsequently incubated 6 hours at $37^{\circ} \mathrm{C}$ to ensure full accumulation of phosphorated HSP27 [26].

Immunocytochemistry was used for the detection of HSP27 phosphorylation by using the protocol detailed in [12]. Briefly, after exposure cells were fixed, permeabilized, and incubated with Phosphorylated HSP27 primary antibody (PhosphoHSP27 (Ser82), ref 2406, Cell Signaling Technology, Danvers, MA) diluted at 1:200. Then, cells were washed and incubated with fluorescent secondary antibody at 1:1000 dilution (Alexa Fluor 488 Goat anti-Rabbit, ref A-11034, Invitrogen, Waltham, MA) and Hoechst $33342(10 \mu \mathrm{g} / \mathrm{mL}$, Sigma-Aldrich) for nuclei counterstaining. HSP27 is one of the most abundant HSP in humans and it is expressed throughout the human body [27]. Overexpression of HSP as well as the variation of its basal level of phosphorylation are indicators that a stress has occurred [28], [29]. Fluorescence analysis was performed cell-by-cell through a high content fluorescence microscope - Cellomics ArrayScan VTI HCS Reader (Thermo Fisher Scientific) - provided by ImPACcell technological platform (Biosit, University of Rennes 1, Rennes, France). Specifically, phosphorylation of HSP27 was precisely mapped as a function of the distance from the center of the exposure, within a 30.25 $\mathrm{mm}^{2}$ area taken in the center of the well, i.e. the area where the specific absorption rate (SAR) and the corresponding temperature elevation were higher (Fig. 2). The area under consideration was subdivided into 121 units of $0.25 \mathrm{~mm}^{2}$ each to be photomicrographed. Axial shift of $0 \mathrm{~mm}$ was assigned to the photomicrograph (PMGs) located in the center of the well (PMG No. 1 in Fig. 2), i.e. aligned with the boresight axis of 
the open-ended WG. Axial shift of other PGMs is calculated according to their distance from the boresight axis. Each PMG contained in average about 100 cells.

\section{B. Microscale Temperature Measurements}

Measurement of local temperature during in vitro experiments at MMW is challenging since the EM power is concentrated within few tenths of $\mathrm{mm}$ from the surface of exposed sample, resulting in high temperature gradients. $\mu \mathrm{TC}$ provides high accuracy in local measurement of temperature at the cellular level (as detailed in [30]) but it may locally affect EM field and temperature (see sections $A$ and $B$ of Results). In this study, a K-type $\mu \mathrm{TC}$ probe (RS Components, Corby, UK) with the leads of $75-\mu \mathrm{m}$ diameter was used. The $\mu \mathrm{TC}$ leads were attached to the bottom of the well with a tape, leaving the $\mu \mathrm{TC}$ tip free of any adhesive material. The probe was aligned with the exposure beam axis, coinciding with the axis of the exposed well, and set either perpendicular or parallel to the $\mathbf{E}$ field. To measure the voltage across the $\mu \mathrm{TC}$ and convert it to temperature, the Thermocouple Reference Design (Microchip Technology, Chandler, AZ) - a printed circuit board (PCB) with an 18-bit Analog-to-Digital Converter (ADC)- was used with sampling interval of $156 \mathrm{~ms}$. The software Thermal Management Utility (Microchip Technology) was used to plot the temperature dynamics.

Temperature measurements and cell exposures were performed in separate experiments to avoid possible cellular damage or contamination as well as local increase of SAR in the cell monolayer due to the presence of the $\mu \mathrm{TC}$ (see sections $A$ and $B$ of Results). Indeed, the presence of the cells induces an approximatively $1 \%$ drop of the incoming energy absorbed by the culture medium [30], that affects only slightly the temperature dynamics [24] (differences $<1 \%$ compared to measurements with cells). Temperature measurements were repeated 4 times to ensure reproducibility.

\section{Electromagnetic and Thermal Models}

Numerical simulations were performed with the finite integration technique (FIT) solver of CST Microwave Studio 2018 (CST-Computer Simulation Technology, Dassault Systems, DE). Due to localized absorption of the MMW energy, we simulated only the well that was exposed (of the total 12 wells), which dimensions are given in Fig. 3, filled with $2 \mathrm{ml}$ of culture medium (corresponding to the height of $5.2 \mathrm{~mm}$ ), and the WG (Fig. 3) as we previously detailed [24], [30]. The effects of a thin metallic $\mu \mathrm{TC}$ on the SAR and temperature in the exposed liquid were computed using the $\mathrm{EM}$ and $\mathrm{T}^{\circ}$ solvers of CST. K-type $\mu \mathrm{TC}$ is made of a chromel-alumel alloy ( $90 \%$ nickel). Therefore, we modelled the $\mu \mathrm{TC}$ tip by a $\varnothing 0.3-\mathrm{mm}$ nickel $\left(\sigma=1.43 \times 10^{7} \mathrm{~S} / \mathrm{m}\right.$ and $\left.\rho=8900 \mathrm{~kg} / \mathrm{m}^{3}\right)$ sphere.

A rectangular block of a square cross-section (CS) represented the $\mu \mathrm{TC}$ leads. CS area $\left(\mathrm{A}=5625 \mu \mathrm{m}^{2}\right)$ and length $(10 \mathrm{~mm})$ are equivalent to the measurement setup. The $\mu \mathrm{TC}$ lead was oriented perpendicularly to the $\mathbf{E}$-field to minimize the induced currents and therefore the effect on the induced fields. The mesh adopted for the EM simulation ensured that the $\mu \mathrm{TC}$ discretization spanned its smallest dimension with at least 8 mesh cells. The resulting model of the well with the $\mu \mathrm{TC}$ contained approximately $50 \mathrm{M}$ of mesh cells.

Results of the EM simulation are used as a source in thermal simulations. Specific heat capacity $c_{\mathrm{p}}(\mathrm{J} / \mathrm{K})$ and thermal conductivity $k[\mathrm{~W} /(\mathrm{m} \cdot \mathrm{K})]$ of the culture medium were measured with a differential scanning calorimeter (DSC Q200, TA Instruments, New Castle, DE) and a thermal conductivity analyzer (CTherm Technologies, New Brunswick, CDN), respectively. The values $c_{\mathrm{p}}=4067.3(\mathrm{~J} / \mathrm{K})$ and $k=0.619$ $[\mathrm{W} /(\mathrm{m} \cdot \mathrm{K})]$ that we found were nearly constant in the 32 $52{ }^{\circ} \mathrm{C}$ interval (variations within the $2 \%$ ). Thermal parameters of the polystyrene used to simulate the plastic well were $c_{\mathrm{p}}=$ $1150(\mathrm{~J} / \mathrm{K})$ and $k=0.173[\mathrm{~W} /(\mathrm{m} \cdot \mathrm{K})]$. Thermal parameters of the $\mu \mathrm{TC}$ were $c_{\mathrm{p}}=900(\mathrm{~J} / \mathrm{K})$ and $k=237[\mathrm{~W} /(\mathrm{m} \cdot \mathrm{K})]$. Open boundary conditions were imposed in all outward directions. Heat loss towards external environment was controlled in the numerical model by the emissivity $\epsilon$ and convection heat transfer $h$ coefficient of polystyrene and culture medium. $\epsilon$ was set to 0.97 and 0.95 for the polystyrene and culture medium, respectively. $h$ was set to 19 and 100 for the polystyrene [31] and culture medium [32], respectively.

\section{Results}

\section{A. Experimental Results}

The presence of an electrically-small (i.e. lead diameter $\sim 0.1 \mathrm{~mm}$ ) metallic $\mu \mathrm{TC}$ during in vitro experiments at MMW may locally distort the SAR distribution around the $\mu \mathrm{TC}$. Highly localized peak SAR was observed in proximity of the $\mu \mathrm{TC}$ tip when the $\mu \mathrm{TC}$ leads were set parallel to the $\mathbf{E}$-field [33]-[38]. This may result in inaccurate $\mathrm{T}^{\circ}$ measurements. When the $\mu \mathrm{TC}$ leads are perpendicular to the $\mathbf{E}$-field, induced currents can be minimized [33] reducing SAR and therefore avoiding perturbation of temperature measurements [34]. Thus, correct positioning with respect to E-field is of outmost importance. In order to quantify the effect of orientation on $\mathrm{T}^{\circ}$ measurement in the exposed medium, we compared parallel and perpendicular orientations of the $\mu \mathrm{TC}$.

At $58.4 \mathrm{GHz}$, the dipole length in the culture medium is around $0.8 \mathrm{~mm}\left(\lambda_{\mathrm{CM}} / 2\right.$ [39]). Therefore, $\mu \mathrm{TC}$ with lead dimension $<0.1 \mathrm{~mm}$ (75 $\mu \mathrm{m}$ in this study) cannot act as a resonant dipole. Under this wavelength regime, the $\mu \mathrm{TC}$ acts as a Rayleigh-type scatterer. Therefore, the temperature elevation recorded during the exposure is mainly due to the heating of the exposed sample in contact with the $\mu \mathrm{TC}$. The presence of induced currents was experimentally verified by comparing the temperature elevation in an empty well with and without exposure. The plastic well was exposed and shamexposed to $\mathrm{PW}$ with the pulse duration of $1.5 \mathrm{~s}$ at the generator peak power of $4.2 \mathrm{~W}$.

Under the parallel configuration, the temperature measured by the $\mu \mathrm{TC}$ was about 20 -fold higher compared to the temperature recorded under the perpendicular configuration (Fig. 4). This is due to induced currents, which may lead to the overheating of the $\mu \mathrm{TC}$ tip [35]. On the contrary, the perpendicular orientation of the $\mu \mathrm{TC}$ leads minimized the induced currents, and only negligible temperature increase was 


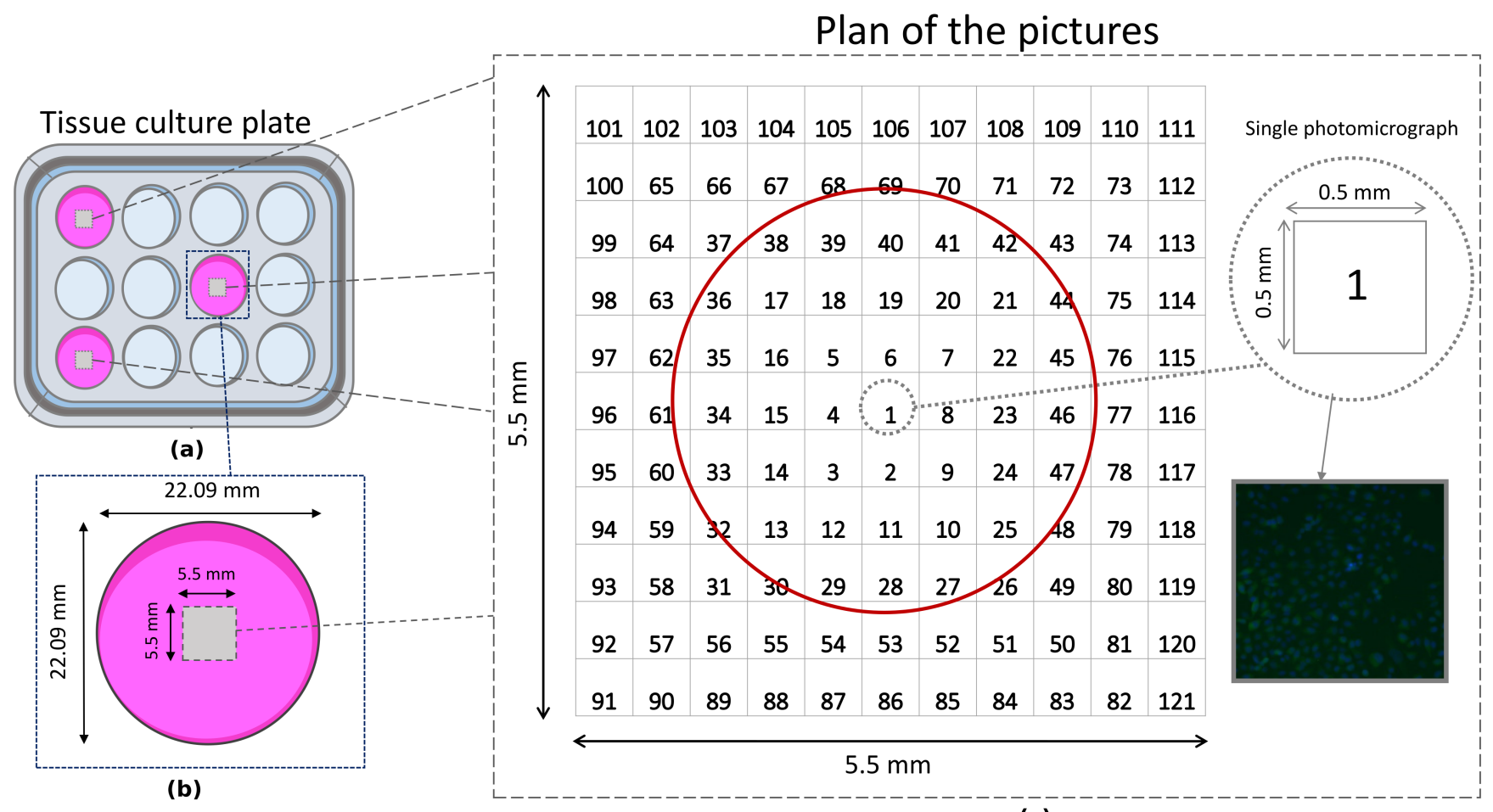

(c)

Fig. 2: (a) 12-well tissue culture plate used for the exposure. (b) Zoom on single well. (c) Plan of photomicrographs (PMGs) taken within each well of the plate. A central area of $30.25 \mathrm{~mm}^{2}(5.5 \times 5.5 \mathrm{~mm})$ contained 121 PMGs. PMG No. 1 of the exposed well is aligned with the boresight axis of the open-ended waveguide. The red circle has a diameter of $1.8 \mathrm{~mm}$.

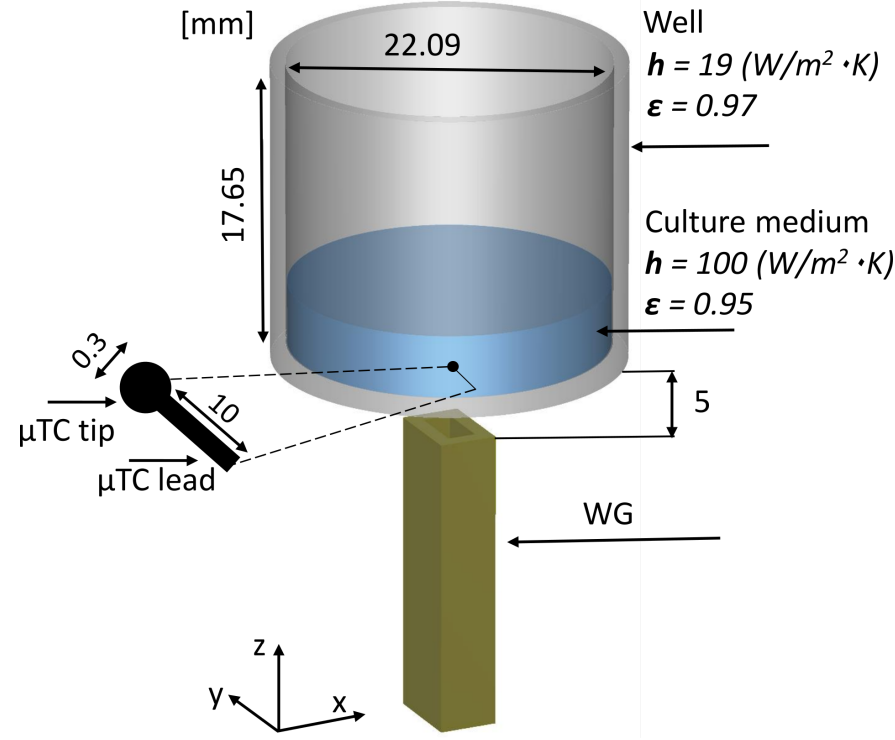

Fig. 3: 3-D model of the exposed well. Zoom of the $\mu \mathrm{TC}$ is shown on the left. Dimensions are not to scale.

measured by the $\mu \mathrm{TC}$. Maximum deviation of about $5 \%$ was observed compared to measurements in absence of exposure (Fig. 4(b)).

\section{B. Numerical Results}

Fig. 5(a) shows the SAR distribution in the culture medium without $\mu \mathrm{TC}$ along the $\mathbf{E}$ - and $\mathbf{H}$ - planes computed at different heights: $z=0 \mathrm{~mm}, z=0.13 \mathrm{~mm}$, and $z=0.4 \mathrm{~mm}$ (corresponding to the maximum SAR value, and its drop by $50 \%$ and $10 \%$, respectively).

The introduction of a $\mu \mathrm{TC}$, with the leads perpendicular to the E-field, results in local increase of SAR close to the $\mu \mathrm{TC}$ tip (in the E-plane), which is more pronounced at $z=$ $0.15 \mathrm{~mm}$ (center of the $\mu \mathrm{TC}$ ) (Fig. 5(b), black line) compared to $z=0 \mathrm{~mm}$. However, SAR deviation around the $\mu \mathrm{TC}$ is only about 5\% higher compared to the SAR obtained without $\mu \mathrm{TC}$, at $z=0 \mathrm{~mm}$ (Fig. 5b, gray line). SAR distributions in the culture medium ( $x y$ plane, $z=0.15 \mathrm{~mm}$ ), computed in a central area of the well of $6 \mathrm{~mm}^{2}$ with and without $\mu \mathrm{TC}$ are presented in Fig. 6. Fig. 6(a) shows the local increase of the SAR in proximity of the $\mu \mathrm{TC}$ tip along $x$ (direction of the E-field). On the contrary, SAR distribution is smooth in the absence of $\mu \mathrm{TC}$ [Fig. 6(b)]. However, the maximum difference in the temperature elevation with and without the TC were about $0.5^{\circ} \mathrm{C}$. Average change in temperature on the $\mu \mathrm{TC}$ surface is $0.2^{\circ} \mathrm{C}$. The temperature distribution computed along $x$ shows that the presence of $\mu \mathrm{TC}$ perpendicular to $\mathbf{E}$ field does not produce error larger than $1.6 \%$ when measuring heating in points in contact with $\mu \mathrm{TC}$ (Fig. 7). This error varies with height along the well axis; however, it remains $\leq 1.6 \%$. These results indicate that, despite the local SAR perturbation, the heating dynamics of the culture medium with and without 


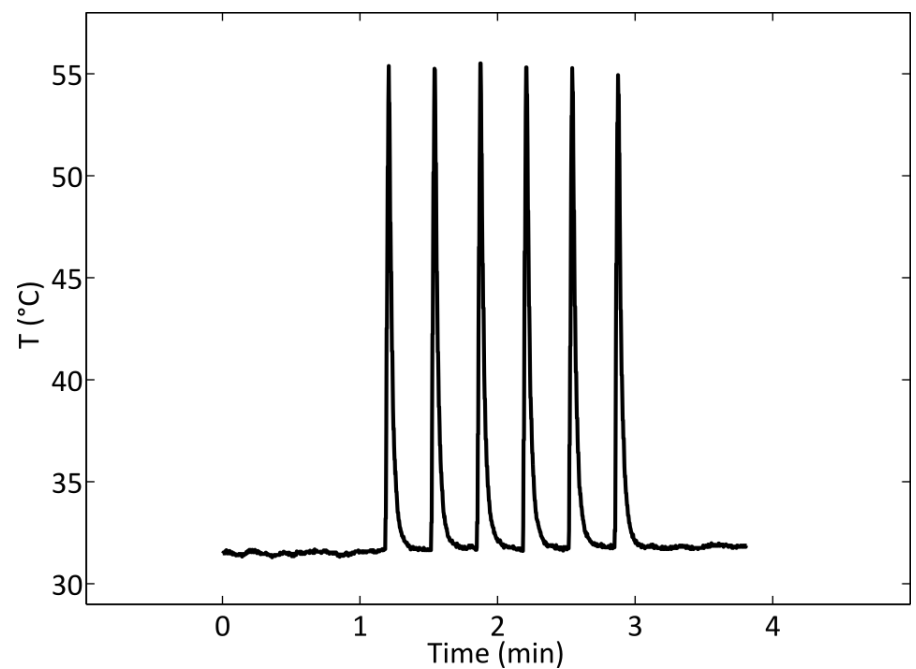

(a)

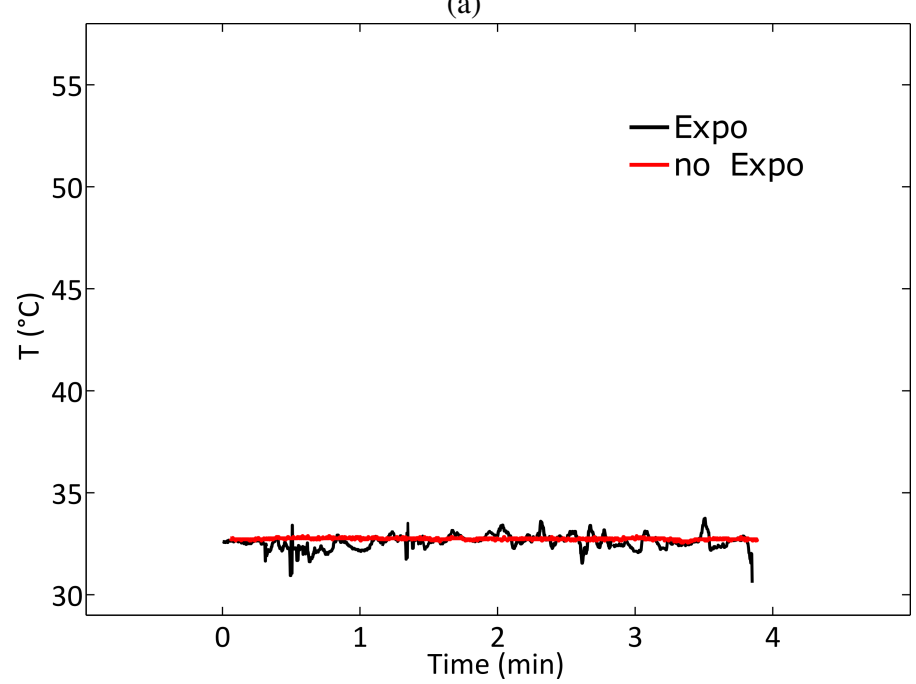

(b)

Fig. 4: Temperature dynamics in an empty well in PW regime with a pulse duration of $1.5 \mathrm{~s}$ at $4.2 \mathrm{~W}$ for (a) parallel and (b) perpendicular orientations of the $\mu \mathrm{TC}$ leads with respect to the $\mathbf{E}$-field.

$\mu \mathrm{TC}$ could be considered equivalent given the $\mu \mathrm{TC}$ leads are oriented perpendicular to incident $\mathbf{E}$-field and the $\mu \mathrm{TC}$ dimensions are much smaller than the effective wavelength $\left(\lambda_{\mathrm{CM}}=1.63 \mathrm{~mm}, \varnothing_{\mathrm{TC}}=0.3 \mathrm{~mm}\right)$.

In order to evaluate the effects of $h$ as well as of $\epsilon$ on heating of the exposed culture medium, a parametric analysis was performed. Specifically, we varied the culture medium parameters in $h_{\mathrm{CM}} \in[80,120], \epsilon_{\mathrm{CM}} \in[0.93,0.97]$ ranges, and the polystyrene well parameters in $h_{\mathrm{pol}} \in[16,22], \epsilon_{\mathrm{pol}} \in[0.95$, 0.99] ranges. Results showed that the variation of $\epsilon$ has no effect on the temperature distribution in the culture medium, while a slight variation (within 3\% [Fig. 8]) was observed when varying $h_{\mathrm{CM}}$ and $h_{\mathrm{pol}}$.

\section{Heat Shock Response}

Phosphorylation of HSP27 was used as a marker of heatinduced cellular stress after $90 \mathrm{~min}$ of exposure at $37-47^{\circ} \mathrm{C}$.

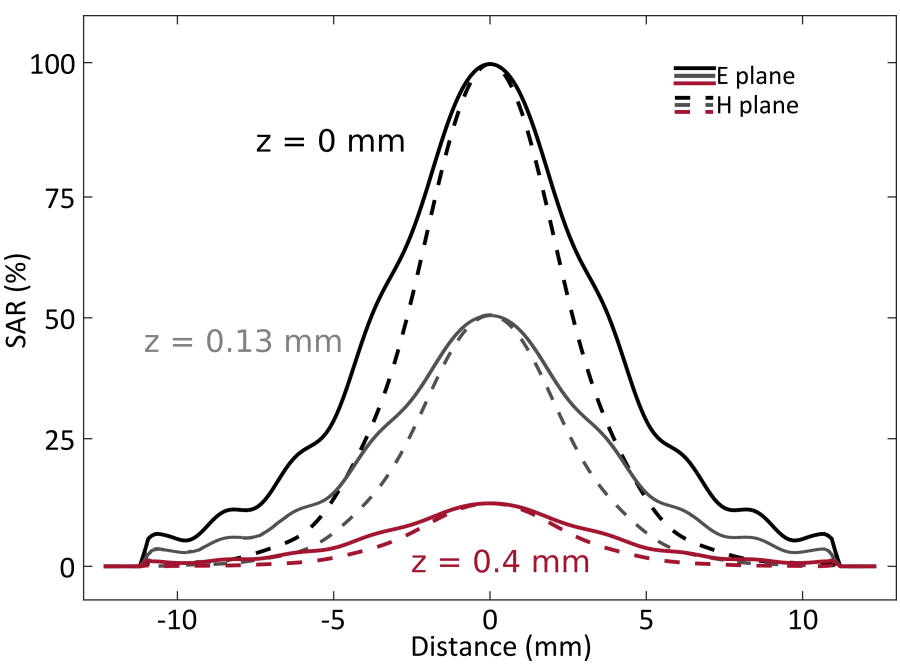

(a)

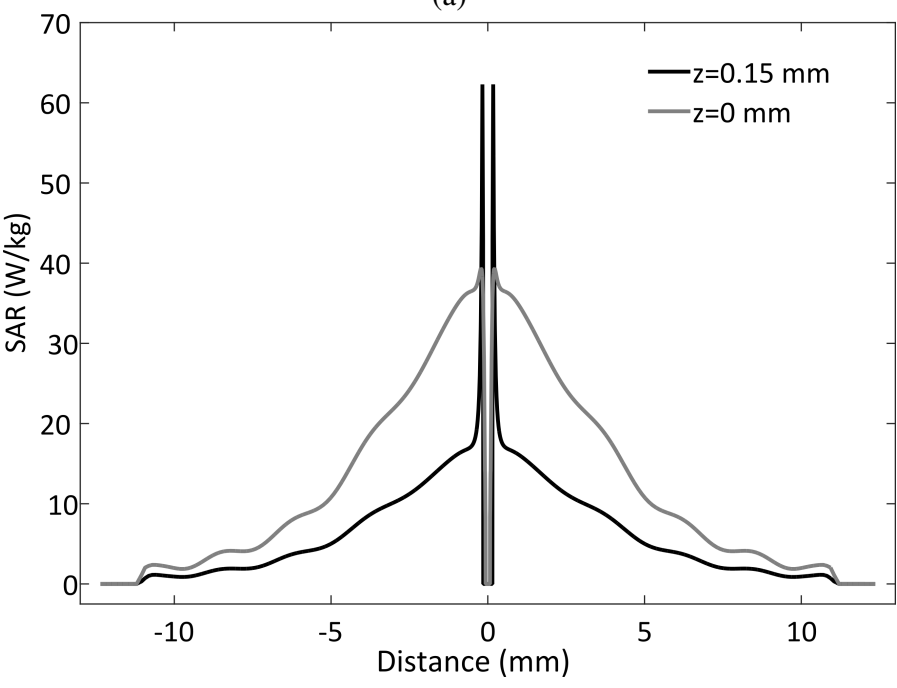

(b)

Fig. 5: (a) SAR without $\mu \mathrm{TC}$ at $z=0 \mathrm{~mm}, z=0.13 \mathrm{~mm}$, and $z=0.4 \mathrm{~mm}$, along the well axis in the $\mathbf{E}$ - and $\mathbf{H}$ - planes. (b) Computed SAR with $\mu \mathrm{TC}$ at $z=0 \mathrm{~mm}$ and $z=0.15 \mathrm{~mm}$ along the E-plane.

HSP27 may protect cellular proteins from aggregation [40] or interfere with the apoptotic machinery to prevent cellular death [26]. Therefore, knowing the induction of HSP27 phosphorylation as a function of temperature might help to optimize hyperthermic treatments, avoiding anti-apoptotic response of the cancer cells [21].

In this study, cells were exposed for 90 minutes between 37 and $47^{\circ} \mathrm{C}$ [Fig. 9(a) and Table I]. Note that the steady state was reached approximately 40-50 minutes after the beginning of exposure. Required temperature dynamics were obtained by varying the input power of the open-ended WG between 120 and $430 \mathrm{~mW}$ corresponding to SAR values between 4.6 and $17 \mathrm{~kW} / \mathrm{kg}$ [Fig. 9(a)]. Temperature curves refer to local measurements in the center of the exposed well (point 1 of Fig. 2). Measurements standard deviation was of $\pm 0.3^{\circ} \mathrm{C}$. Due to localized absorption of MMW energy, induced temperature elevation is reduced as moving away from the center of the 


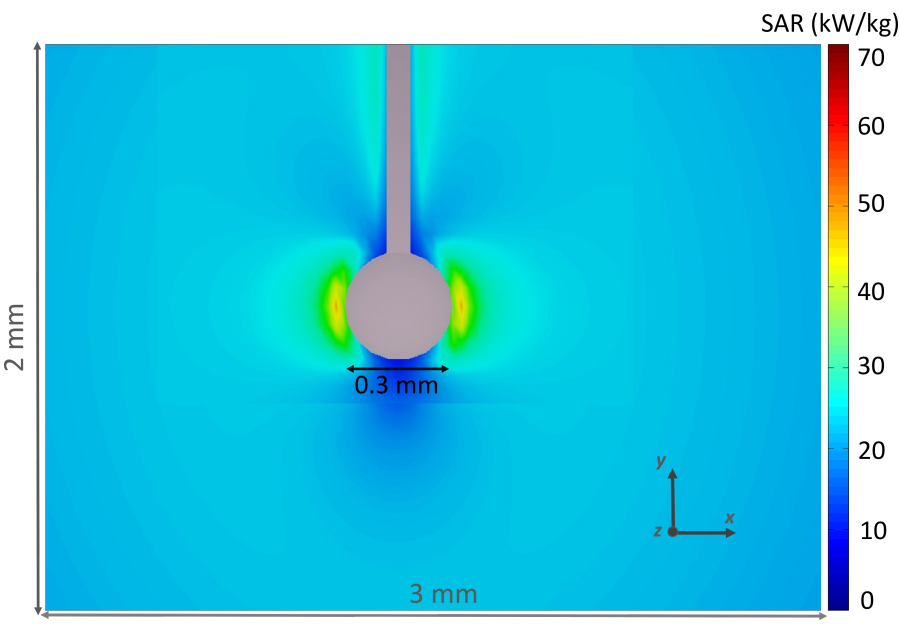

(a)

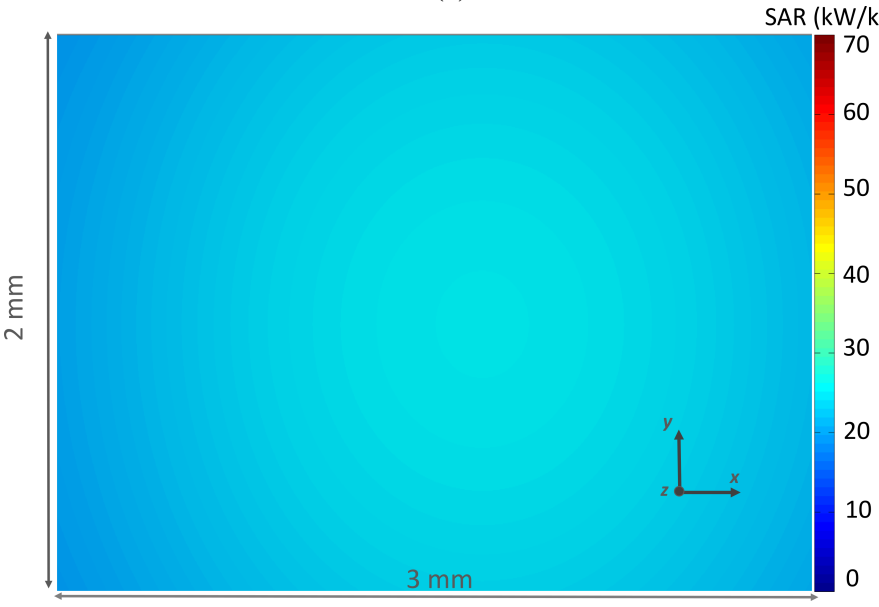

(b)

Fig. 6: (a) SAR distribution in the center of the well (a) with and (b) without $\mu \mathrm{TC}$ in the $x y$ plane at $z=0.15 \mathrm{~mm}$.

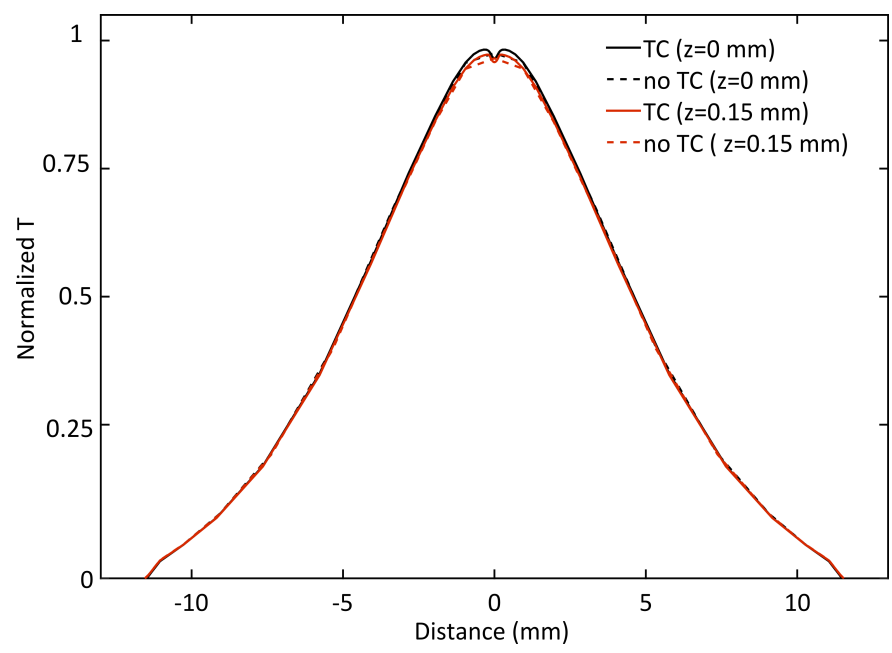

Fig. 7: Normalized computed heat distribution along $x$ with and without the $\mu \mathrm{TC}$ at $z=0 \mathrm{~mm}$ and $z=0.15 \mathrm{~mm}$. Data are normalized to the maximum temperature.

well. However, only a slight decrease of the peak temperature $(\sim 10 \%)$ was observed for $d>2.5 \mathrm{~mm}$ [Fig. 2(c)] when cells

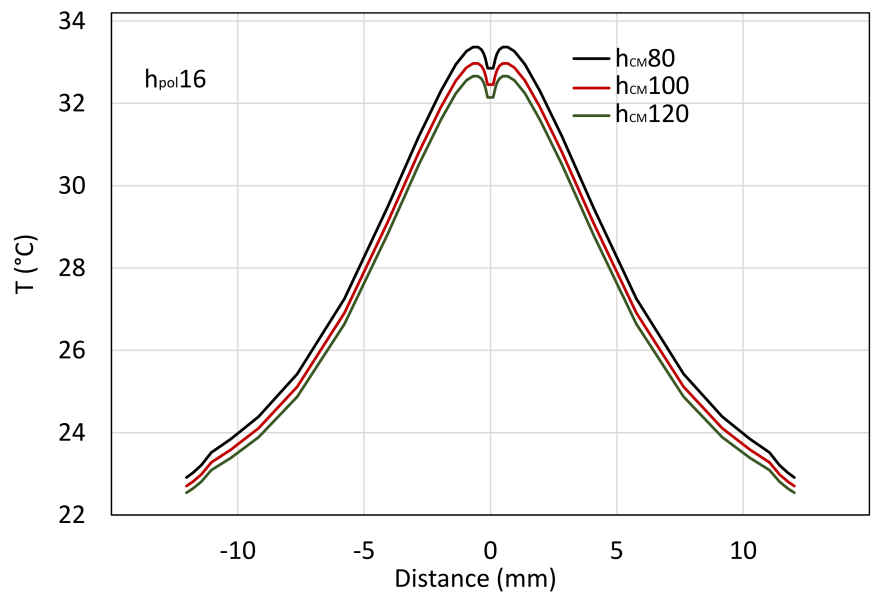

(a)

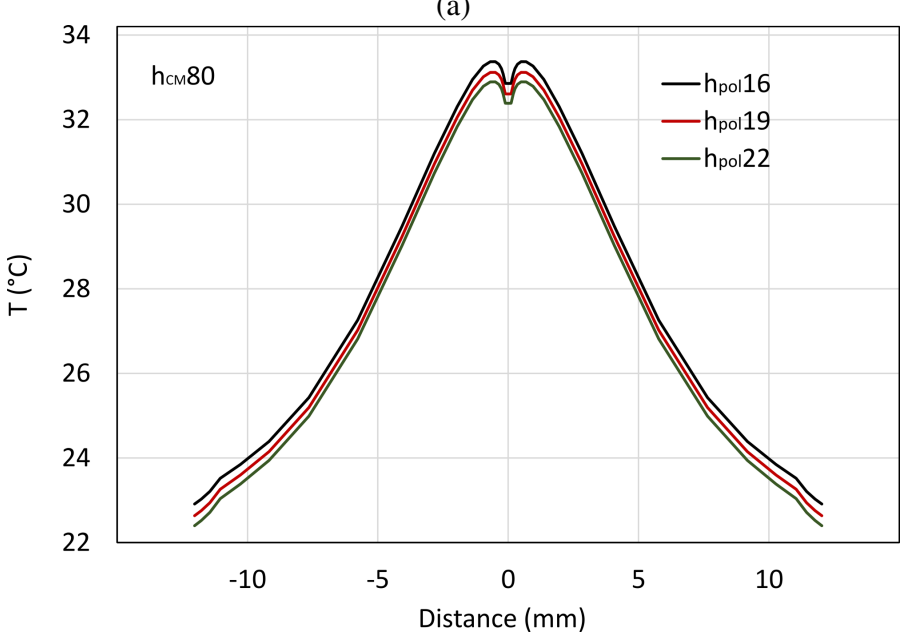

(b)

Fig. 8: Temperature elevation in the culture medium along $x$ axis crossing the middle of the $\mu \mathrm{TC}$ for a) $h_{\mathrm{CM}} \in[80,120]$ and $h_{\mathrm{pol}}=16$, and b) $h_{\mathrm{pol}} \in[16,22]$ and $h_{\mathrm{CM}}=80$.

were exposed at peak SAR of $10 \mathrm{~W} / \mathrm{kg}$ at $d=0 \mathrm{~mm}$, i.e. steady state temperature of about $42.5^{\circ} \mathrm{C}$ [12]. A similar behavior was assumed for all the curves considered in this study.

Phosphorylation of HSP27, after 6 hours of recovery at $37^{\circ} \mathrm{C}$ was analyzed as a function of distance from the center of the exposure, within $30.25 \mathrm{~mm}^{2}$ area (Fig. 2). Data are presented as $n$-fold induction over the sham controls [Fig. 9(b)]. Two areas have been considered in the analysis, namely the central area with radius of $1.8 \mathrm{~mm}$ (i.e. red circle in Fig. 2, with SAR variation within the $25 \%$ ), and the one located at $1.8 \mathrm{~mm}<d<3.5 \mathrm{~mm}$ (SAR variation between $75 \%$ and $50 \%$ of the maximum value). Results show an exponential increase of the level of the protein phosphorylation as the thermal dose increases (Table I). The latter was quantified with the cumulative equivalent minutes at $43^{\circ} \mathrm{C}\left(\mathrm{CEM} 43^{\circ} \mathrm{C}\right)$, introduced in 1984 [41] and widely used in hyperthermia [42]. This parameter allows to quantify the exposure by converting the time-temperature history in an equivalent number of minutes at $43^{\circ} \mathrm{C}$ : 


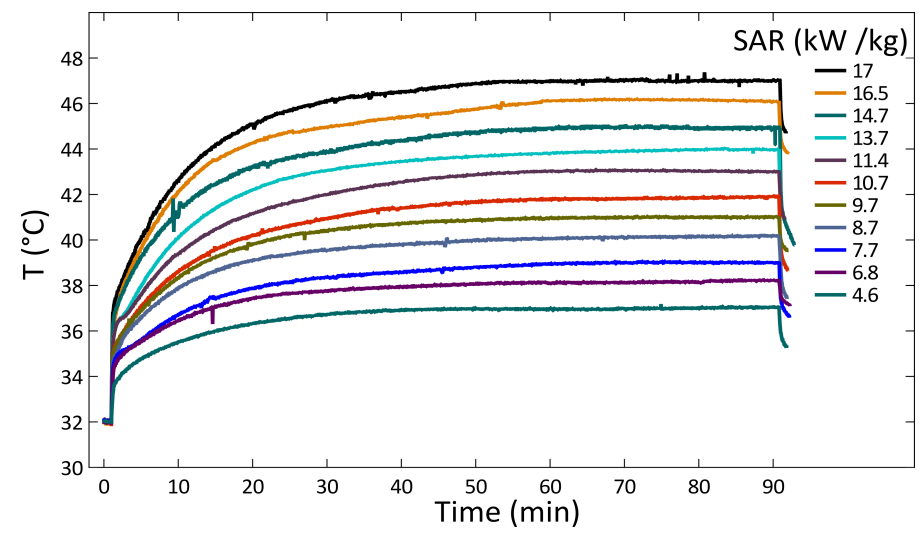

(a)

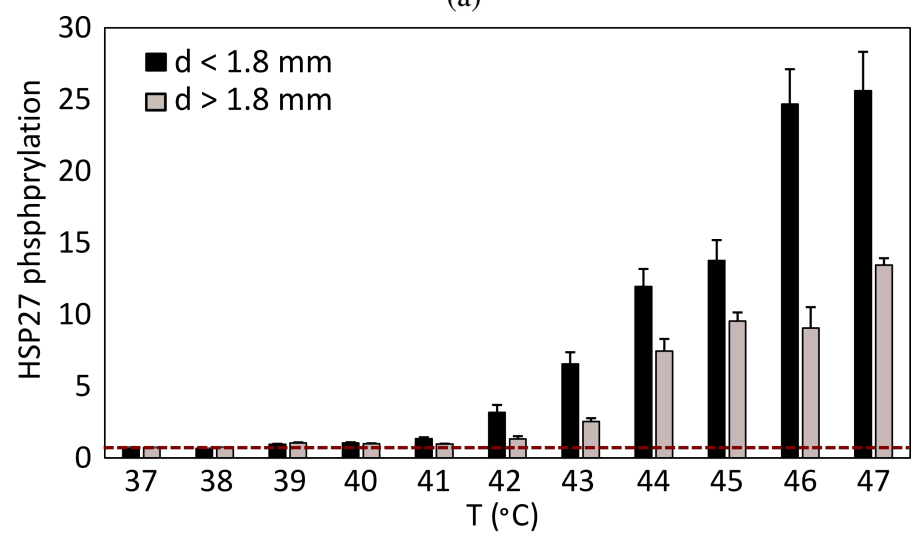

(b)

Fig. 9: (a) Temperature dynamics during 90 min of exposure to $\mathrm{CW}$ within the $4.6-17 \mathrm{~kW} / \mathrm{kg}$ SAR interval. (b) Phosphorylation of HSP27 as a function of the temperature between 37 and $47^{\circ} \mathrm{C}$, for the $\mathrm{A} 375$ melanoma cell line, at $0<d<1.8 \mathrm{~mm}$ and $d>1.8 \mathrm{~mm}$. Temperature $\left[\mathrm{T}\left({ }^{\circ} \mathrm{C}\right)\right]$ refers to local steady state temperature at $d=0 \mathrm{~mm}$. Data are normalized to the sham and presented as mean \pm standard error of the mean. Red dashed line represents sham.

$$
\mathrm{CEM} 43^{\circ} \mathrm{C}=\int_{0}^{t} R^{[43-T(t)]} d t
$$

where $O$ and $t$ represent the beginning and the end of the heating period, respectively, $T(t)$ is the heat time profile, and $R$ is an experimentally-determined constant allowing to compensate for $1^{\circ} \mathrm{C}$ temperature change either above or below $43^{\circ} \mathrm{C}$ to obtain the same cellular survival fraction. $R$ varies depending on the cell line [14], [43]. We used $R\left(T<43^{\circ} \mathrm{C}\right)=$ 0.233 and $R\left(T>43^{\circ} \mathrm{C}\right)=0.428$, derived from human skin cells in vitro [44].

Our results show that phosphorylation of HSP27 is triggered at temperatures $\geq 41^{\circ} \mathrm{C}\left(\mathrm{CEM} 43^{\circ} \mathrm{C} \geq 3.2\right)$. At $41^{\circ} \mathrm{C}$, a slight increase (about 1.4-fold of the sham) of the cellular response is induced in proximity of the WG axis $(0<d<1.8 \mathrm{~mm})$. At $42^{\circ} \mathrm{C}\left(\sim 10 \mathrm{CEM} 43^{\circ} \mathrm{C}\right)$, heat shock in the area with radius of $1.8 \mathrm{~mm}$ is significantly stronger compared to the sham (about 3-fold), and it rapidly decreases at $d>1.8 \mathrm{~mm}$. Note, that for the specific cell line, under the same exposure conditions of this study, temperature of about $42.5^{\circ} \mathrm{C}(\sim 24$
CEM $43^{\circ} \mathrm{C}$ ) generated thermotolerance, as suggested by the fact that the triggering of HSP27 phosphorylation did not correlate with cellular apoptosis [12]. Finally, we observed that for temperatures $\geq 43^{\circ} \mathrm{C}\left(49<\mathrm{CEM} 43^{\circ} \mathrm{C}<1815\right)$, HSP27 phosphorylation induced in the exposed cells is higher than the sham within the whole area, although it is more pronounced in the central area of the exposure, with the maximum values of induction up to 25 -fold of the sham (i.e. at $46^{\circ} \mathrm{C}$ and $47^{\circ} \mathrm{C}$ ).

Chaperone activity of phosphorylated HSP27, i.e. its ability to protect stressed proteins, varies as a function of temperature in the $20-48^{\circ} \mathrm{C}$ interval [45]. Specifically, at temperatures between 20 and $30^{\circ} \mathrm{C}$, the ability of HSP27 to protect cells is nearly constant, presenting a steep increase between 37 and $43^{\circ} \mathrm{C}$. The latter has been identified as the breakpoint temperature in the cell survival curves in most of the mammalian cells and it likely represents the upper limit at which thermotolerance can be induced [46]. At higher temperatures (up to $48^{\circ} \mathrm{C}$ ), the curve showing the behavior of the chaperone activity of HSP27 as a function of temperature flattens: only a slight increase of the chaperone activity is observed between 44 and $48^{\circ} \mathrm{C}$. This is in agreement with a previous study [12], where the saturation of the HSP27 response was observed when cells were exposed to peak temperatures between 47 and $49^{\circ} \mathrm{C}$. Indeed, at these temperatures, the highest level of HSP27 phosphorylation correlated with the highest level of apoptosis. When cells were exposed to about $48^{\circ} \mathrm{C}$, despite the maximum chaperon activation, the cell protection mechanism based on induction of HSP27 phosphorylation and other heat shock proteins did not cope with increasing heat damage of cells [12]. In addition, 2 hours of exposure at $45^{\circ} \mathrm{C}$ (cell culture located in a heated water bath) reduces cellular viability of the A375 melanoma cell line by about $40 \%$ while only $25 \%$ of reduction was observed at $43^{\circ} \mathrm{C}$ [47].

At $43^{\circ} \mathrm{C}$, heat shock response of the considered cell line is not at its maximum, thereby being still able to protect cells from dying; only exceeding $46-47^{\circ} \mathrm{C}$ heat shock response saturates. $43^{\circ} \mathrm{C}-47^{\circ} \mathrm{C}$ range corresponds to an intermediate situation where some cells start to die despite the protective heat shock response and some continue to resist, via the heat shock response and activation of chaperones, which also have an anti-apoptotic activity. Results of this study suggest that the phosphorylation of HSP27 represents a valuable marker of cellular stress of A375 melanoma cells under MMW exposure, providing quantitative information on distribution of the thermal stress.

\section{CONCLUSIONS}

Cellular response to heat strongly varies among different cell lines [14]. The knowledge of the specific sensitivity of the cell line of interest in terms of cell survival or cellular resistance is critical for success of a thermal treatment. Classical predictive models of the induced damage [48], including the $\mathrm{CEM} 43^{\circ} \mathrm{C}$, are based on an Arrhenius-type relationship, which describes the evolution of thermal damage of cells or tissues. However, despite their clinical applications, numerous limitations are related to the use of these models, such as the lack of prediction of thermotolerance [48]. For this reason, 
TABLE I: Specific Absorption Rate (SAR) and Correspondent Temperature Elevation and Cumulative Equivalent Minutes at $43^{\circ} \mathrm{C}\left(\mathrm{CEM} 43^{\circ} \mathrm{C}\right)$ in the $37-47{ }^{\circ} \mathrm{C}$ Temperature Interval

\begin{tabular}{ccc}
\hline SAR $(\mathrm{W} / \mathrm{kg})$ & Temp. $\left({ }^{\circ} \mathrm{C}\right)$ & CEM$^{\circ}{ }^{\circ} \mathrm{C}(\mathrm{min})$ \\
\hline 4.6 & 37 & 0.01 \\
6.8 & 38 & 0.05 \\
7.7 & 39 & 0.17 \\
8.7 & 40 & 0.9 \\
9.7 & 41 & 3.2 \\
10.7 & 42 & 10.2 \\
11.4 & 43 & 49.4 \\
13.7 & 44 & 130.3 \\
14.7 & 45 & 286.3 \\
16.5 & 46 & 816.2 \\
17 & 47 & 1815 \\
\hline
\end{tabular}

an alternative model has been recently proposed to consider, beyond exposure duration and resulting heating, the level of chaperone expression as a mean to provide complementary information about the thermal resistance of a cell line [14].

The aim of this study was to evaluate the phosphorylation of a small molecular chaperone - HSP27 - induced in the A375 melanoma cell line following $90 \mathrm{~min}$ of exposure to CW MMW heating as a marker of the cellular stress within the hyperthermic range between 37 and $47^{\circ} \mathrm{C}$ (at steps of $1^{\circ} \mathrm{C}$ ). MMW-induced heating was used instead of a water bath to realistically mimic future $\mathrm{MMW}$-hyperthermic treatment. Note that the temperature rise rate and dynamics are different for MMW and water bath. Numerical modeling and measurements were performed to assure that the use of a thin metallic $\mu \mathrm{TC}$ (lead $\varnothing 75 \mu \mathrm{m}$ ) does not perturb the temperature elevation within the exposed sample, provided that its tip is perpendicular to the E-field. This ensures artefact-free measurement of the temperature dynamics during the exposure, critical for correct interpretation of experimental biological data.

HSP27 phosphorylation was quantified cell-by-cell as a function of distance from the WG axis. Our results demonstrated that the HSP response in A375 malignant melanoma cells is triggered at temperatures $\geq 41{ }^{\circ} \mathrm{C}$, and it increases exponentially with temperature (Fig. 9). Overall, our results suggest that preferably cells have to be exposed above $46^{\circ} \mathrm{C}$ to minimize cellular thermotolerance while inducing apoptosis. Moreover, the analysis as a function of distance from the WG shows that the thermal stress is mainly focused within a small area with a radius of $1.8 \mathrm{~mm}$. This suggests that MMW heating can be efficiently and selectively focused within a small region of interest avoiding damage of the non-cancerous tissue nearby the tumor.

Results of this study provide helpful indications for preliminary planning and optimization of clinical treatment of superficial spreading melanoma. Extension of these results to other cell lines constitutes one of the main perspectives of this study. However, as in vitro results may largely vary from in vivo responses [49], further investigations are needed on tissue models. In addition, the knowledge of cell survival curves in the thermal range of interest, might be complementary to the current study for a more complete characterization of the cellular sensitivity of cells to MMW-induced heating. Analysis of impact of the exposure duration on the induction of HSP27 phosphorylation as well as on cellular apoptosis is one of the perspectives of this study.

\section{ACKNOWLEDGEMENTS}

Authors would like to acknowledge Dr. Stanislav Alekseev, who is no longer with us, for his significant contribution to the study, his priceless knowledge, and great encouragement to always pursue new exciting results. He continues to inspire us by his example and dedication to the research and educations he served over the course of his career.

\section{REFERENCES}

[1] Q. H. Abbasi, M. U. Rehman, K. Qaraqe, and A. Alomainy, Advances in body-centric wireless communication: applications and state of the art. Institution of Engineering and Technology (IET), 2016. OCLC: 986504032.

[2] T. S. Rappaport, S. Sun, R. Mayzus, H. Zhao, Y. Azar, K. Wang, G. N. Wong, J. K. Schulz, M. Samimi, and F. Gutierrez, "Millimeter Wave Mobile Communications for 5G Cellular: It Will Work!," IEEE Access, vol. 1, pp. 335-349, 2013. Conference Name: IEEE Access.

[3] J. Hasch, E. Topak, R. Schnabel, T. Zwick, R. Weigel, and C. Waldschmidt, "Millimeter-Wave Technology for Automotive Radar Sensors in the $77 \mathrm{GHz}$ Frequency Band," IEEE Transactions on Microwave Theory and Techniques, vol. 60, pp. 845-860, Mar. 2012. Conference Name: IEEE Transactions on Microwave Theory and Techniques.

[4] C. Richard, J. Barber, J. Lehman, G. B. McHugh, K. C. R. Ii, N. Bompensa, J. C. Weatherall, P. R. Smith, D. Karns, Z. Landicini, A. J. Whitehead, J. Devine, B. Masters, and B. T. Smith, "A protocol for simulant validation using active millimeter-wave imaging systems," in Passive and Active Millimeter-Wave Imaging XXIII, vol. 11411, p. 114110A, International Society for Optics and Photonics, Apr. 2020.

[5] B. Zohuri, "Millimeter-Wave Energy as Weapon," in Directed-Energy Beam Weapons (B. Zohuri, ed.), pp. 377-396, Cham: Springer International Publishing, 2019.

[6] M. Zhadobov, N. Chahat, R. Sauleau, C. Le Quement, and Y. Le Drean, "Millimeter-wave interactions with the human body: state of knowledge and recent advances," International Journal of Microwave and Wireless Technologies, vol. 3, pp. 237-247, Apr. 2011.

[7] M.-O. Mattsson, O. Zeni, and M. Simkó, "Is there a Biological Basis for Therapeutic Applications of Millimetre Waves and THz Waves?," Journal of Infrared, Millimeter, and Terahertz Waves, vol. 39, pp. 863878, Sept. 2018.

[8] M. Simkó and M.-O. Mattsson, "5G Wireless Communication and Health Effects-A Pragmatic Review Based on Available Studies Regarding 6 to $100 \mathrm{GHz}$,' International Journal of Environmental Research and Public Health, vol. 16, no. 18.

[9] Y. Le Dréan, Y. S. Mahamoud, Y. Le Page, D. Habauzit, C. Le Quément, M. Zhadobov, and R. Sauleau, "State of knowledge on biological effects at 40-60 GHz," Comptes Rendus Physique, vol. 14, pp. 402-411, May 2013.

[10] M. Zhadobov, S. Alekseev, Y. L. Dréan, R. Sauleau, and E. E. Fesenko, "Millimeter waves as a source of selective heating of skin.," Bioelectromagnetics, 2015.

[11] B. S. Kalal, D. Upadhya, and V. R. Pai, "Chemotherapy resistance mechanisms in advanced skin cancer," Oncology Reviews, vol. 11, p. 326, Mar. 2017.

[12] R. Orlacchio, Y. Le Page, Y. Le Dréan, R. Le Guével, R. Sauleau, S. Alekseev, and M. Zhadobov, "Millimeter-wave pulsed heating in vitro : cell mortality and heat shock response," Scientific Reports, vol. 9, pp. 1-11, Oct. 2019. Number: 1 Publisher: Nature Publishing Group.

[13] I. Szabo, S. Alekseev, G. Acs, A. Radzievsky, M. Logani, V. Makar, O. Gordiienko, and M. Ziskin, "Destruction of cutaneous melanoma with millimeter wave hyperthermia in mice," IEEE Transactions on Plasma Science, vol. 32, pp. 1653-1660, Aug. 2004. Conference Name: IEEE Transactions on Plasma Science.

[14] D. Labavić, M. Ladjimi, E. Courtade, B. Pfeuty, and Q. Thommen, "Mammalian cell sensitivity to hyperthermia in various cell lines: a new universal and predictive description," International Journal of Hyperthermia, vol. 37, pp. 506-516, Jan. 2020. Publisher: Taylor \& Francis. 
[15] J. L. R. Roti, "Cellular responses to hyperthermia $\left(40-46^{\circ} \mathrm{C}\right)$ : Cell killing and molecular events," International Journal of Hyperthermia, vol. 24, pp. 3-15, Jan. 2008

[16] R. W. Y. Habash, R. Bansal, D. Krewski, and H. T. Alhafid, "Thermal therapy, part 1: an introduction to thermal therapy," Critical Reviews in Biomedical Engineering, vol. 34, no. 6, pp. 459-489, 2006.

[17] H. H. Kampinga, J. R. Dynlacht, and E. Dikomey, "Mechanism of radiosensitization by hyperthermia ( $>$ or $=43$ degrees $C$ ) as derived from studies with DNA repair defective mutant cell lines," International Journal of Hyperthermia: The Official Journal of European Society for Hyperthermic Oncology, North American Hyperthermia Group, vol. 20, pp. 131-139, Mar. 2004.

[18] G. M. Hahn and G. C. Li, "Thermotolerance and heat shock proteins in mammalian cells," Radiation Research, vol. 92, pp. 452-457, Dec. 1982.

[19] R. I. Morimoto, "The heat shock response: systems biology of proteotoxic stress in aging and disease," Cold Spring Harbor Symposia on Quantitative Biology, vol. 76, pp. 91-99, 2011.

[20] J. Becker and E. Craig, "Heat-shock proteins as molecular chaperones.," European journal of biochemistry, vol. 219 1-2, pp. 11-23, 1994.

[21] M. N. Rylander, Y. Feng, K. Diller, and J. Bass, "Design of optimal hyperthermia protocols for prostate cancer by controlling HSP expression through computer modeling (Invited Paper)," vol. 5698, pp. 247-254 Apr. 2005. Conference Name: Thermal Treatment of Tissue: Energy Delivery and Assessment III.

[22] Y. Liu, P. Chongsathidkiet, B. M. Crawford, R. Odion, C. A. Dechant, H. R. Kemeny, X. Cui, P. F. Maccarini, C. D. Lascola, P. E. Fecci, and T. Vo-Dinh, "Plasmonic gold nanostar-mediated photothermal immunotherapy for brain tumor ablation and immunologic memory," Immunotherapy, vol. 11, pp. 1293-1302, Oct. 2019.

[23] Y. Liu, P. Maccarini, G. M. Palmer, W. Etienne, Y. Zhao, C.-T. Lee, X. Ma, B. A. Inman, and T. Vo-Dinh, "Synergistic Immuno Photothermal Nanotherapy (SYMPHONY) for the Treatment of Unresectable and Metastatic Cancers," Scientific Reports, vol. 7, p. 8606, Aug. 2017. Number: 1 Publisher: Nature Publishing Group.

[24] R. Orlacchio, M. Zhadobov, S. Alekseev, D. Nikolayev, R. Sauleau, Y. 1. Page, and Y. L. Dréan, "Millimeter-wave heating in in vitro studies: effect of convection in continuous and pulse-modulated regimes.," Bioelectromagnetics, 2019.

[25] A. J. Haas, Y. Le Page, M. Zhadobov, R. Sauleau, and Y. Le Dréan, "Effects of $60-\mathrm{GHz}$ millimeter waves on neurite outgrowth in PC12 cells using high-content screening," Neuroscience Letters, vol. 618, pp. 5865, Apr. 2016

[26] P. Pandey, R. Farber, A. Nakazawa, S. Kumar, A. Bharti, C. Nalin, R. Weichselbaum, D. Kufe, and S. Kharbanda, "Hsp27 functions as a negative regulator of cytochrome c-dependent activation of procaspase3," Oncogene, vol. 19, pp. 1975-1981, Apr. 2000.

[27] T. R. Alderson, J. Roche, H. Y. Gastall, D. M. Dias, I. Pritišanac, J. Ying, A. Bax, J. L. P. Benesch, and A. J. Baldwin, "Local unfolding of the HSP27 monomer regulates chaperone activity," Nature Communications, vol. 10, p. 1068, Mar. 2019. Number: 1 Publisher: Nature Publishing Group.

[28] W. J. Welch, "Phorbol ester, calcium ionophore, or serum added to quiescent rat embryo fibroblast cells all result in the elevated phosphorylation of two 28,000-dalton mammalian stress proteins," The Journal of Biological Chemistry, vol. 260, pp. 3058-3062, Mar. 1985.

[29] A.-P. Arrigo, "Mammalian HspB1 (Hsp27) is a molecular sensor linked to the physiology and environment of the cell," Cell Stress \& Chaperones, vol. 22, pp. 517-529, July 2017.

[30] M. Zhadobov, S. I. Alekseev, R. Sauleau, Y. Le Page, Y. Le Dréan, and E. E. Fesenko, "Microscale temperature and SAR measurements in cell monolayer models exposed to millimeter waves," Bioelectromagnetics, vol. 38, pp. 11-21, Jan. 2017.

[31] R. Conti, A. A. Gallitto, and E. Fiordilino, "Measurement of the convective heat-transfer coefficient," The Physics Teacher, vol. 52, pp. 109-111, Feb. 2014. arXiv: 1401.0270.

[32] T. L. Bergman, A. S. Lavine, and F. P. Incropera, Fundamentals of Heat and Mass Transfer, 7th Edition. John Wiley \& Sons, Incorporated, Mar. 2011. Google-Books-ID: 5cgbAAAAQBAJ.

[33] S. Alekseev and M. Ziskin, "Distortion of millimeter-wave absorption in biological media due to presence of thermocouples and other objects," IEEE Transactions on Biomedical Engineering, vol. 48, pp. 10131019, Sept. 2001. Conference Name: IEEE Transactions on Biomedical Engineering.

[34] S. Alekseev and M. Ziskin, "Local Heating of Human Skin by Millimeter Waves: A Kinetics Study,” Bioelectromagnetics, vol. 24, pp. 571-81, Dec. 2003.
[35] S. I. Alekseev, M. C. Ziskin, and E. E. Fesenko, "Problems of using a thermocouple for measurements of skin temperature rise during the exposure to millimeter waves," Biophysics, vol. 56, p. 525, Aug. 2011.

[36] R. T. Constable, P. Dunscombe, A. Tsoukatos, and K. Malaker, "Perturbation of the temperature distribution in microwave irradiated tissue due to the presence of metallic thermometers," Medical Physics, vol. 14, pp. 385-388, June 1987.

[37] P. B. Dunscombe, J. McLellan, and K. Malaker, "Heat production in microwave-irradiated thermocouples," Medical Physics, vol. 13, pp. 457-461, Aug. 1986.

[38] P. B. Dunscombe, R. T. Constable, and J. McLellan, "Minimizing the self-heating artefacts due to the microwave irradiation of thermocouples," International Journal of Hyperthermia: The Official Journal of European Society for Hyperthermic Oncology, North American Hyperthermia Group, vol. 4, pp. 437-445, Aug. 1988.

[39] C. A. Balanis, Antenna theory: analysis and design. John Wiley \& Sons, Dec. 2015. Google-Books-ID: PTFcCwAAQBAJ.

[40] A.-P. Arrigo and B. Gibert, "HspB1 dynamic phospho-oligomeric structure dependent interactome as cancer therapeutic target," Current Molecular Medicine, vol. 12, pp. 1151-1163, Nov. 2012.

[41] S. A. Sapareto and W. C. Dewey, "Thermal dose determination in cancer therapy," International Journal of Radiation Oncology*Biology*Physics, vol. 10, pp. 787-800, Apr. 1984.

[42] G. C. van Rhoon, "Is CEM43 still a relevant thermal dose parameter for hyperthermia treatment monitoring?," International Journal of Hyperthermia: The Official Journal of European Society for Hyperthermic Oncology, North American Hyperthermia Group, vol. 32, no. 1, pp. 5062, 2016.

[43] W. C. Dewey, "Arrhenius relationships from the molecule and cell to the clinic," International Journal of Hyperthermia: The Official Journal of European Society for Hyperthermic Oncology, North American Hyperthermia Group, vol. 25, pp. 3-20, Feb. 2009.

[44] J. A. Pearce, "Comparative analysis of mathematical models of cell death and thermal damage processes," International Journal of Hyperthermia: The Official Journal of European Society for Hyperthermic Oncology, North American Hyperthermia Group, vol. 29, pp. 262-280, June 2013.

[45] B. Lelj-Garolla and A. G. Mauk, "Self-association of a small heat shock protein," Journal of Molecular Biology, vol. 345, pp. 631-642, Jan. 2005.

[46] M. W. Dewhirst, B. L. Viglianti, M. Lora-Michiels, M. Hanson, and P. J. Hoopes, "Basic principles of thermal dosimetry and thermal thresholds for tissue damage from hyperthermia," International Journal of Hyperthermia: The Official Journal of European Society for Hyperthermic Oncology, North American Hyperthermia Group, vol. 19, pp. 267-294, June 2003.

[47] T. Mantso, S. Vasileiadis, I. Anestopoulos, G. P. Voulgaridou, E. Lampri, S. Botaitis, E. N. Kontomanolis, C. Simopoulos, G. Goussetis, R. Franco, K. Chlichlia, A. Pappa, and M. I. Panayiotidis, "Hyperthermia induces therapeutic effectiveness and potentiates adjuvant therapy with nontargeted and targeted drugs in an in vitro model of human malignant melanoma," Scientific Reports, vol. 8, p. 10724, July 2018.

[48] J. A. Pearce, "Models for thermal damage in tissues: processes and applications," Critical Reviews in Biomedical Engineering, vol. 38, no. 1, pp. $1-20,2010$.

[49] C. Jensen and Y. Teng, "Is It Time to Start Transitioning From 2D to 3D Cell Culture?," Frontiers in Molecular Biosciences, vol. 7, 2020. Publisher: Frontiers. 